\section{Breaking Gender Digital Division Through the Use of Virtual Classroom}

\author{
Abdulganiyu A. Amosa ${ }^{1}$ \\ Oyeronke O. Ogunlade ${ }^{2}$ \\ Olutayo O. Obielodan ${ }^{3}$ \\ Department of Educational Technology \\ University of Ilorin, Ilorin, Nigeria ${ }^{1,2,3}$ \\ Email: bleglom@gmail.com \\ http://ojs.unm.ac.id/index.php/Insani/index
}

Abstract. Virtual classroom is a teaching-learning situation where participants can interact with the tutor and electronic learning materials in an online setting. Thus, the study on gender equity and the use of virtual classroom needs to be addressed so as to ensure its full integration into the teaching-learning process. Therefore, this study geared towards determining gender gap in the lecturers' use of virtual classroom in teaching-learning process. Participants were 117 lecturers ( 83 male lecturers and 34 female lecturers) from the Faculties of Education and, Communication and Information Sciences, University of Ilorin, Nigeria. The data collected through a questionnaire were analyzed using mean and t-test statistical tools. Findings revealed amongst others that virtual classroom enhanced teaching-learning process as perceived by lecturers. Also, majority of both male and female lecturers have positive attitude towards the use virtual classroom for bridging gender gap in teaching-learning process. Hence, the attitude of the lecturers towards the use of virtual classroom revealed a major implication that the lecturers are confronted with the network problem, which gives limitation to the use of virtual classroom. This underscores the need to support and provide virtual learning environment that would ease the use of virtual classroom for teaching-learning effectiveness

Key words: Virtual classroom; Lecturers; Gender Division; Attitude; Utilization

\section{INDONESIAN \\ JOURNAL OF EDUCATIONAL STUDIES (IJES)}

\author{
E-ISSN: 2621-6744 \\ P-ISSN: 2621-6736
}

Submitted: March, $28^{\text {th }} 2019$

Accepted: May, $2^{\text {nd }} 2020$

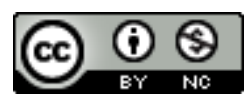

This work is licensed under a Creative Commons Attribution-NonCommercial 4.0 International License 


\section{INTRODUCTION}

Education is the process by which people acquire knowledge, skills, habits, values, attitudes and moral behavior. Education helps people to become useful to themselves and their society. The culture, such as human ways of life, religion, customs, history, language, habits, festivals, arts, technology and other aspects of the civilization of any society is passed on from one generation through education (UNESCO, 2005). The National Policy on Education (FRN, 2013) emphasized the need to integrate information and communication technology (ICT) at all levels of education. Undergraduate students should therefore not develop negative attitude towards the face book as a social media tool for learning.

The rate at which learners are coping with ICT for learning cannot be over emphasized. The pedagogical approach of ICT based-learning is on technology of education and technology in education on the preparation of learners toward the integration and utilization of technology in educational setting. Hence, the most commonly reason for using ICT in education has been to prepare the students to tackle future encounters where ICT devices encourage the quality of education by increasing learners' engagement and inspiration, enabling the attainment of basic skills and facilitating teacher education programme (Ogunlade, Ogunlade \& Obielodan, 2016). The quality of education in the University of Ilorin, Ilorin, Nigeria is encouraging as the students are introduced to the varieties of information and communication technology learning strategy such as virtual classroom learning environment. Virtual classroom refers to electronic communication through which users form online communities to share learning experiences in the context of education.

There are many studies that point out that male students perform better than female students in the STEM disciplines (Coley, 2001; Sanga et al., 2013; Bicer et al., 2015). There are some findings in the literature indicating that male students may be able to take advantage of classroom technology, such as Google forms, Google classroom, virtual classroom better than female students (King \& Joshi, 2008). Furthermore, male students may have perceived the usefulness of a CRS (classroom response system), such as Google classroom, more than female students (Kay, 2009).

There are conditions that facilitate the utilization of virtual classroom. Internet access is one of the major obstacles facing the utilization of virtual classroom among lecturers and students for teaching and learning. In some cases, the network fluctuates and results to malfunction of virtual classroom learning strategy. Virtual classroom illustrates any form of computer and internet instructional strategy, which offers opportunity to learners to have several levels of interaction between the learners to devices, teachers to learners. The benefits of virtual classroom are the ability for the learner to play, replay, pause and rewind to any precise segment of the tape. Parker et al. (2010) remarked that interactivity is a vital role of virtual classroom in teaching-learning process.

The utilization of virtual classroom in teaching-learning process is a means of arresting and focusing learners' attention to meaningful and productive learning experiences. Virtual classroom facilities encompass varieties of synchronous and asynchronous devices, such as e-mail, Newsgroups, Computer based training, quick reference guide, Screen sharing, Online seminar, Video conferencing, among others, to allow the students in the remote areas to be active participants in learning. A virtual classroom allows the participants to collaborate in an online environment and interact with learning materials. The involvement can be through text, video or both (Ferriman, 2013; Arbaugh, 2000). 
The following according to Ferriman (2013) are considered as the advantages of using virtual classroom. A virtual classroom permits both students and tutors around the world to involve in synchronous classes to interact and communicate learners and instructors around the world to participate in live classes to collaborate and interact. The cost embark on the utilization of virtual classroom is inexpensive, since the travelling fees would not be catered as learning holds anywhere and anytime. Moreover, virtual classes offers the ability to record the events as it takes place, together with any form of presentations such audio and visual. This implies that learning experiences are handy and reachable even after the class is being held. Virtual classroom is synchronous in nature, which allows all the participants to involve and interact at the real time. This teaching-learning strategy affords the varieties of similar learning experiences that accompany with accessibilities and devices.

Aldridge (2009) opined that web based instructional strategy providers should provide sufficient technical supports, which should be available for the learners to become active participants. Utilization of virtual classroom as an instructional strategy encourages teachers and learners to integrate it into their day to day educational endeavor. Therefore, their interactions to learning materials becomes usable at both in and outside the classroom. Since the students are ranges of different abilities, background and previous knowledge, online based instruction can be used to address such varieties of the students' demands. This instructional strategy permits students to work at their respective pace, which is the best means of catering for the individual differences of learners. Utilization of virtual classroom in teaching-learning process would assist the learners to have the necessary and quality learning experiences that can bring about meaningful and productive learning. Thus, virtual classroom guarantees greatest value and effectiveness. Irrespective of gender, utilization of virtual classroom for teaching-learning process improves learners from being passive participants to active participants, since such instructional strategy caters for the individual differences of learners. In addition, students' readiness to learn is encouraged if their access to the learning materials can be at their own pace.

The virtual classroom gives supports to instruction. Virtual classroom provides learners with incomparable opportunities to access relevant learning materials for the benefit of learners and instructors. Instructional technologies focus on the technologies used by instructors in providing instruction while learning technologies focuses on the technologies utilized by students for the achievement of specific learning outcomes. (Davies, 2013)

Apart from the fixed resources in traditional CBI, Virtual classroom offers the suitably modified and restructured, readily accessed, and rapidly associated with the related sources of knowledge, hence creating a support for "anytime, anywhere" learning experiences (Ferriman, 2013). Shaw \& Gant (2002) discovered gender similarity as regards the usage of web applications. Male learners had greater tendency to utilize the Internet for recreation, collection and retrieval of information and entertainment. However, females had preference for utilizing the Internet for communication and socialization as they utilized e-mail and prompt transmission of messages over their male counterparts. Also, it was discovered that electronic mail message transmission was the greatest important utility given by the Internet (Bertakis et al., 2000). Females were found to utilize electronic mailing system over male.

It is important that three individuals namely teachers, students and parents should demand technological integration in schools so that their students, children or wards will be equipped to interact with other students who are already technologically inclined and access valid and up-to-date information. This will make them more active in their learning and they 
will be able to utilize different types of resources online and prepare themselves for their future careers. Teachers will also be able to keep abreast of the latest technology (Ballew, 2017).

\section{RESEARCH METHOD}

This study is a quantitative method using survey approach. Descriptive survey research type was adopted. The population for this study consisted of all lecturers of University of Ilorin, Ilorin, Nigeria. A total of 117 lecturers from the Faculties of Education and Communication and Information Sciences were randomly sampled for the study. The instrument for this study was a questionnaire designed by the researchers, using the 4-point Likert Scale response modes: Strongly Agree (SA - 4), Agree (A - 3), Disagree (D - 2) and Strongly Disagree (SD - 1). Thus, four research questions and two research hypotheses were answered and tested using mean rating and t-test statistical tool respectively. The research questions one and two were answered by converting frequencies to mean, while research questions three and four were answered through the corresponding hypotheses one and two. Moreover, hypotheses one and two were tested using t-test to find out significant difference between male and female lecturer. All hypotheses were tested at (0.05) level of significance.

\section{RESULT AND DISCUSSION}

This section presents the analysis and interpretation of data collected for this study. Data obtained in respect of research questions were analyzed using mean and the research hypotheses were tested using t-test.

\section{Demographic Information of Respondents}

The distribution of lecturers involved in the study based on gender showed that there was a difference in the distribution along gender lines. Table 1 shows that (83) $70.9 \%$ were male lecturers in all the sampled respondents while (34) $29.1 \%$ of them were female lecturers.

Table 1. Respondents based on Gender

\begin{tabular}{ccc}
\hline Lecturers & Frequency & Percentage $(\%)$ \\
\hline Male & 83 & 70.9 \\
Female & 34 & 29.1 \\
\hline
\end{tabular}

\section{Lecturer's responses on the use of virtual classroom}

Table 2 shows the responses of lecturers in using virtual clasroom. There are 12 statements used to measure the variable.

Table 2. Analysis of lecturers' responses on the use of virtual classroom for bridging gender gap in teaching-learning process

\begin{tabular}{clc}
\hline No & \multicolumn{1}{c}{ Statement } & Mean \\
\hline 1 & Teaching through virtual classroom is gender biased & 1.74 \\
\hline 2 & $\begin{array}{l}\text { Virtual classroom provides information on learning } \\
\text { experience for both male and female lecturers }\end{array}$ & 3,25 \\
\hline
\end{tabular}




\begin{tabular}{clc}
\hline 3 & $\begin{array}{l}\text { Irrespective of gender in virtual classroom can make a big } \\
\text { difference in narrowing the digital divide }\end{array}$ & 3,45 \\
\hline 4 & $\begin{array}{l}\text { Lecturers irrespective of gender are encouraged to use } \\
\text { virtual classroom for teaching }\end{array}$ & 3.27 \\
\hline 5 & $\begin{array}{l}\text { Involvement of both male and female lecturers in the skill } \\
\text { acquisition of online }\end{array}$ & 3.23 \\
\hline 6 & learning affords gender equality in performing teaching & 3.15 \\
\hline 7 & $\begin{array}{l}\text { Gender advocates in the virtual classroom arena call for the } \\
\text { realization of gender equality within the ICT sector diffusion } \\
\text { that contributes to positive change in gender relations }\end{array}$ & 3.37 \\
\hline 9 & $\begin{array}{l}\text { Using virtual classroom to teach could be frustrating } \\
\text { classroom for teaching }\end{array}$ & 3.22 \\
\hline 10 & $\begin{array}{l}\text { Conventional teaching is preferred to virtual classroom } \\
\text { Utilization of virtual classroom for teaching is energy } \\
\text { consuming, thus it is suitable only for male not female } \\
\text { lecturers }\end{array}$ & 3.37 \\
\hline 12 & $\begin{array}{l}\text { Virtual classroom based instruction guarantees teaching } \\
\text { effectiveness for male than female lecturers }\end{array}$ & 3.38 \\
\hline
\end{tabular}

Based on the results in table 2, it was revealed that the lecturers' responses established with the mean rating of 2.92 that the use of virtual classroom could be meaningfully used for bridging gender gap in teaching-learning process. This may be as a result of their exposure and understanding about virtual classroom.

\section{Lecturers' opinion on the usefulness of virtual classroom in teaching-learning process}

Table 3 shows the responses of lecturers related the usefulness in using virtual clasroom. There are 11 statements used to measure the variable.

Table 3. Analysis of lecturers' responses on the usefulness of virtual classroom in teachinglearning process

\begin{tabular}{clc}
\hline No & Statement & Mean \\
\hline 1 & $\begin{array}{l}\text { The use of virtual classroom for teaching provides good } \\
\text { avenue for efficient and effective teaching-learning process }\end{array}$ & 3.28 \\
\hline 2 & $\begin{array}{l}\text { Learners' individualized learning strategy is achieved } \\
\text { through virtual Classroom }\end{array}$ & 3.44 \\
\hline 3 & $\begin{array}{l}\text { Use of virtual classroom helps to cover wider learning } \\
\text { experience }\end{array}$ & 3.23 \\
\hline 4 & $\begin{array}{l}\text { The virtual classroom is used to solve difficult concepts in } \\
\text { teaching-learning process }\end{array}$ & 3.43 \\
\hline 5 & $\begin{array}{l}\text { Virtual classroom improves students' academic } \\
\text { performance }\end{array}$ & 3.42 \\
\hline 7 & Virtual Classroom is not useful for all disciplines & 3.37 \\
\hline
\end{tabular}




\begin{tabular}{clc}
\hline 8 & The use of virtual classroom motivates me to teach & 3.43 \\
\hline 9 & $\begin{array}{l}\text { Using virtual classroom offers learning assisted instruction } \\
\text { for learners }\end{array}$ & 3.27 \\
\hline 10 & $\begin{array}{l}\text { Virtual classroom could be counter productivity due to } \\
\text { insufficient technical Resources }\end{array}$ & 3.45 \\
\hline 11 & $\begin{array}{l}\text { Virtual classroom will eliminate eye contact and reduces } \\
\text { students' seriousness }\end{array}$ & 3.38 \\
\hline & Grand Mean & 3.4 \\
\hline
\end{tabular}

Based on the results in table 3, it was revealed that the lecturers' responses established with the mean rating of 3.4 that the use of virtual classroom could facilitate and improve teaching-learning process and students' academic performance. This response was as a result of their individual exposure to virtual classroom .

\section{Hypotheses Testing}

Ho:: There is no significant difference between male and female lecturers' opinion on the use of virtual classroom for bridging gender gap in teaching-learning process

Table 4. Significant difference in the opinion of male and female lecturers on the use of virtual classroom for bridging gender gap

\begin{tabular}{llllllll}
\hline Variable & No & Mean & $\begin{array}{c}\text { Std. } \\
\text { deviation }\end{array}$ & df & t-value & Sig.(2-tailed) & Remarked \\
\hline Male & 83 & 3.3593 & .1931 & 115 & -0.65 & 0.516 & Accepted \\
Female & 34 & 3.3850 & .1965 & & & & \\
\hline
\end{tabular}

NS - Not Significant at $p>0.05$

From Table 4, analysis established that the $t$-value $=-0.65$, with $p$-value of $0.516>0.05$ alpha level. This implies that the null hypothesis one, which states that there is no significant difference between male and female lecturers' opinion on the use of virtual classroom for bridging gender gap showed no significant difference. Hence, the hypothesis one was accepted. Therefore, there was no significant difference between the opinion of male and female lecturers on the use of virtual classroom for bridging gender gap.

$\mathrm{Ho}_{2}$ : There is no significant difference between male and female lecturers' opinion on the usefulness of virtual classroom in teaching-learning process

Table 5. Significant difference in the opinion of male and female lecturers in the usefulness of virtual classroom on teaching-learning process

\begin{tabular}{lccccccc}
\hline Variable & No & Mean & $\begin{array}{c}\text { Std. } \\
\text { deviation }\end{array}$ & Df & t-value & Sig.(2-tailed) & Remarked \\
\hline Male & 83 & 2.9036 & .2219 & 115 & -1.534 & 0.128 & Accepted \\
Female & 34 & 2.9706 & .1948 & & & & \\
\hline
\end{tabular}


From Table 5, analysis established that the t-value $=-1.534$, with p-value of $0.128>0.05$ alpha level. This implies that the null hypothesis two, which states that there is no significant difference between male and female lecturers' opinion on the usefulness of virtual classroom on teaching-learning process showed no significant difference. Hence, the hypothesis two was accepted. Therefore, there was no significant difference between the opinion of male and female lecturers on the usefulness of virtual classroom in teachinglearning process.

The results showed that the use of virtual classroom could be meaningfully used for bridging gender gap in teaching-learning process. The use of virtual classroom could facilitate and improve teaching-learning process and students' academic performance. The role of virtual classroom in instructional delivery strategies in teaching-learning process cannot be overemphasized. It is a type of learning through which learners can learn at their own pace. As such it has been revealed from this study that virtual classroom facilitates teaching-learning process and improves students' academic performance. This study corroborated Venkatesh, (2000) who discovered gender disparity in individual implementation and continual usage of technology for occupational purpose. In the study, men's decisions were more strongly influenced by their attitude towards using the new technology, while women were more strongly influenced by their subjective norm and perceived behavior control. In addition, students' readiness to learn and lecturers' determination to be efficient are encouraged if access to learning materials can be easy.

\section{Contributions to Knowledge}

The contributions of this study to knowledge is built on the training of University of Ilorin academic staff members on the use of google Apps for education in order to increase their efficiency and engagement in the use of information and communication technology facilities in teaching-learning process. Thus, the application of google Apps for education affords the utilization of virtual classroom as an instructional delivery method among lecturers and students in the University. Likewise, virtual classroom, if encouraged to be fully incorporated into the teaching and learning, learning would be more interactive, collaborative and not gender biased. Finally, teaching-learning will not be restricted to the conventional method, where if the teacher not in class teaching process cannot take place.

\section{CONCLUSION}

The findings from this study indicated that virtual classroom facilitates teachinglearning process affords individualized learning strategy among learners, thus this study recommends that the institutions should sustain the training of its academic members with the encouragement that the lecturers should fully inculcate virtual classroom in teachinglearning process. Poor access to the internet due to low bandwidth subscription can be addressed by increasing the width being subscribed to by the institution. Training and retraining on the utilization virtual classroom should be prolonged to the students in order to improve their expertise in the utilization ICT instructional delivery methods. Finally, lecturers irrespective of gender should remain to be encouraged on the full integration of virtual classroom in teaching-learning process. 


\section{REFERENCES}

Aldridge, J., Fraser, B., \& Ntuli, S. (2009). Utilising learning environment assessments to improve teaching practices among in-service teachers undertaking a distanceeducation programme. South African Journal of Education, 29(2).

Arbaugh, J. B. (2000). Virtual classroom characteristics and student satisfaction with internet-based MBA courses. Journal of management education, 24(1), 32-54.

Ballew, T. D. (2017). Teacher Perceptions of a Technology-based Google Classroom. CarsonNewman University.

Bertakis, K. D., Azari, R., Helms, L. J., Callahan, E. J., \& Robbins, J. A. (2000). Gender differences in the utilization of health care services. Journal of family practice, 49(2), 147-147.

Bicer, A., Navruz, B., Capraro, R. M., Capraro, M. M., Oner, T. A., \& Boedeker, P. (2015). STEM schools vs. non-STEM schools: Comparing students' mathematics growth rate on high-stakes test performance. International Journal of New Trends in Education and Their Implications, 6(1), 138-150.

Coley, R. J. (2001). Differences in the gender gap: Comparisons across racial/ethnic groups in communications systems (ICCS). Computers \& Education, 52(4), 730-740.

Davies, R. S. (2013). Technology Integration in Schools. Handbook of Research on Educational Communications and Technology, 5-6.

FRN - Federal Republic of Nigeria. (2013). National policy on education. Lagos: NERDC Press.

Ferriman, J. (2013). Characteristics of a Virtual Classroom. Retrieved from, www.eduwire.com/technology /characteristics-of-a-virtual-classroom/

Kay, R. H. (2009). Examining gender differences in attitudes toward interactive classroom communication system (ICCS). Computers \& Education, 52(4): 730-740.

Kayalar, F. (2016). Cross-cultural comparison of teachers' views upon integration and use of technology in classroom. The Turkish Online Journal of Educational Technology, 15(2), pp. 11-19.

King, D. B., \& Joshi, S. (2008). Gender differences in the use and effectiveness of personal response devices. Journal of Science Education and Technology, 17(6), 544-552.

Martin, F \& Parker, M. A. (2014). Use of Synchronous Virtual Classrooms: Why, Who,and How? MERLOT Journal of Online Learning andTeaching, 10(2), 192-210.

Ogunlade, O. O.; Ogunlade, A. A. \& Obielodan, O. O. (2016). Enhancing learning through information and communication technology: University of Ilorin pre-service teachers' perception. Malaysian Journal of Distance Education 18(1):71-85. http://d x.doi.org/10.21315/m jde2016.18.1.5

Parker, M. A., Grace, E. R., \& Martin, F. (2010). Do you teach in a Virtual Classroom?: Measuring student's perceptions of the features and characteristics. INSTRUCTIONAL TECHNOLOGY, 17.

UNESCO. (2005). Guidelines and Recommendations for Reorienting Teacher Education to Address Sustainability. Retrieved from www.unesco.org/new/en/education/.../ education.../teacher-education/

Sanga, C., Magesa, M., Chingonikaya, E., \& Kayunze, K. (2013). Can e-learning promote participation of female students in STEM disciplines in higher learning institutions of Tanzania?. International Journal of Education and Development using ICT, 9(3).

Shaw, L. H., and Gant, L. M. (2002) 'Users divided? Exploring the gender gap in Internet use', Cyber psychology and Behavior. 5(6), 517-527. 